\title{
The nature of Late Cenozoic volcanism in the Udokan Range, northwestern segment of the Baikal Rift Zone
}

\author{
A. F. Grachev ${ }^{1}$ \\ Received 7 October 2016; accepted 10 November 2016; published 7 January 2017.
}

Newly obtained major-component, trace-element, and rare-earth element (REE) analyses are used to gain insight into the nature of Late Cenozoic volcanism in the Udokan Range. The composition of the lavas is analyzed in each lava flow and it is demonstrated that the rocks define a bimodal differentiated series with a Daly gap. The absence of andesite is seen not only in the summarizing diagrams but also in individual vertical sections of the volcanic rocks. The petrochemical specifics of volcanics in the Udokan Range involves broad variations in the $\mathrm{TiO}_{2}$ concentrations: from 0.22 to $4.41 \mathrm{wt} \%$. The REE patterns of the volcanics show a trend analogous to that of oceanic islands basalts (OIB). The compositional specifics of the rocks suggest that the basalt-trachyte series was derived from a single mantle source related to a mantle plume. KEYWORDS: Volcanism; Daly gap; mantle plume; Baikal Rift; Udokan Range.

Citation: Grachev, A. F. (2017), The nature of Late Cenozoic volcanism in the Udokan Range, northwestern segment of the Baikal Rift Zone, Russ. J. Earth. Sci., 17, ES1001, doi:10.2205/2017ES000578.

\section{Introduction}

The Udokan Range in the northeastern segment of the Baikal Rift Zone affiliates with the Chara Rift and is noted for volcanic activity that gave rise to both plateau basalts and central-type volcanoes.

The very first data on the age of volcanism in the Udokan Range were obtained in the 1960s: tuff-breccia found in the bottom portion of a basalt pile contained a pollen spectrum dated at the Pliocene-Quaternary [Muzis, 1970. Later a young (Quaternary) age of the basalt was confirmed in [Solonenko, 1966, although no new evidence had then been obtained.

Our studies of five vertical sections in the lowermost portion of the basalt-underlying unit resulted in finds of volcanic-sedimentary or sedimentary rocks that rest on either older basalt or granite (Figure 1). Pollen data (obtained by A. N. Smirnova, V. A. Belova, M. P. Grichuk, and V. M. Klimanova) have shown that the rocks underlying the basalt are of Quaternary age, no older than the older epoch (at most). The age of the underlying basalt was uncertain.

The very first K-Ar dates of the basalts were obtained in 1970 at a laboratory of the Institute of the Geology of Ore Deposits, Petrography, Mineralogy, and Geochemistry

\footnotetext{
${ }^{1}$ Schmidt Institute of Physics of the Earth, Russian Academy of Sciences, Moscow, Russia

Copyright 2017 by the Geophysical Center RAS.

http://elpub.wdcb.ru/journals/rjes/doi/2017ES000578-res.html
}

(IGEM), Russian Academy of Sciences, using basalt samples from the areas of Lake Burichi and Lake Kuas: $2.5 \pm 0.5$ and $5 \pm 1.0 \mathrm{Ma}$, respectively.

Later the values of 9.5 and 16 Ma were published in [Kiselev et al., 1979]. The 35 dates published in [Bagdasaryan et al., 1981 average at $5.55 \pm 3.35 \mathrm{Ma}$ (with two deviating values of 11.75 and $14.0 \mathrm{Ma}$ ). If these two dates are ignored, the average age of the Udokan basalt is $4.27 \pm 1.67 \mathrm{Ma}$. The dates (13 measurements) obtained thereafter in [Amirkhanov et al., 1985 yield an amazing average of $24 \pm 4 \mathrm{Ma}$, but the authors do not report their sampling sites, the composition of the rocks, or detail of the dating technique. Similarly presented data can be found in [Stupak, 1987]. The absence of information on the Ar concentrations, blanks, and details of the analytical techniques make it impossible to utilize these data.

Later the samples dated by M.M. Arakelyants at IGEM were dated again in [Drubetskoi and Grachev, 1987] (Table 1, with all the dates consistent within the analytical errors. The average age values of the Udokan basalt is $4.40 \pm 1.55 \mathrm{Ma}$ Table 1 and practically exactly coincide with the value of 4.27 $\pm 1.67 \mathrm{Ma}$ in Bagdasaryan et al., 1981.

Several K-Ar and ${ }^{40} \mathrm{Ar} /{ }^{39} \mathrm{Ar}$ dates presented in [Rasskazov et al., 2000 indicate that the volcanics were erupted at $14,8.7-7.4,4-2.4$, and $<1.8 \mathrm{Ma}$.

Below we discuss the specifics of volcanism in the Udokan Range over the past 2.5-3.0 Ma, with the total volume of the volcanic products amounting to no less than $500 \mathrm{~km}^{3}$. Recently made chemical analyses of the volcanics and their concentrations of trace elements are then utilized to discuss the nature of volcanism in the Udokan Range. 


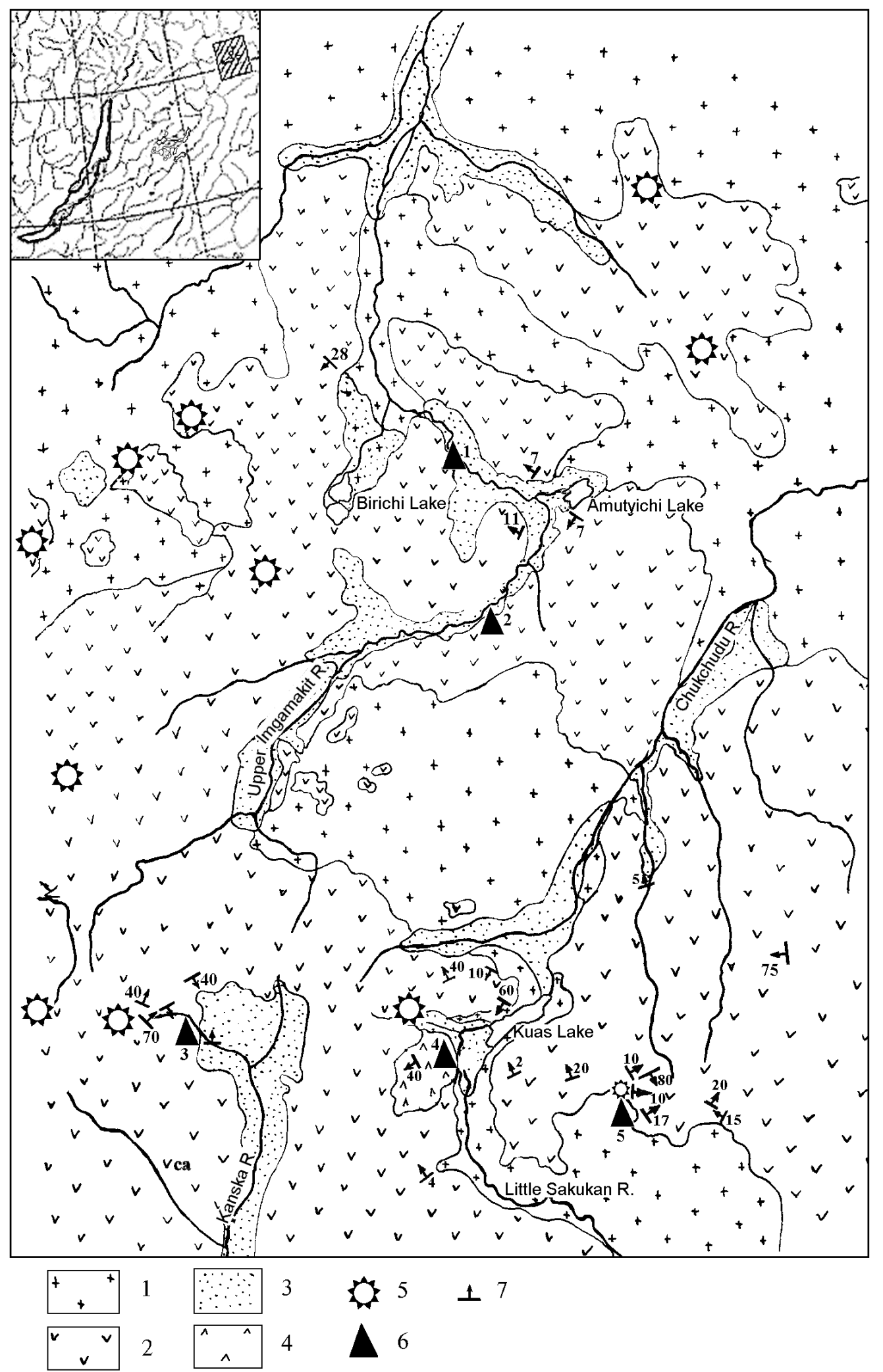

Figure 1. Schematic map of sedimentary rocks underlying the basalt, 1 - Basement granite; 2 trachybasalt; 3 - sedimentary rocks; 4 - trachyte; 5 - volcanoes; 6 - sites where sedimentary rocks underlying the basalt were found; 7 - strike and dip symbols of rocks. 
Table 1. K-Ar Age of Basalt From the Udokan Range

\begin{tabular}{|c|c|c|c|c|c|c|c|}
\hline Sample & Rock & Sampling site & $\mathrm{K}, \%$ & ${ }^{40} \mathrm{Ar}, 10^{-8} \mathrm{~cm}^{3} / \mathrm{g}$ & ${ }^{40} \mathrm{Ar}, \mathrm{rad}$ & Age, Ma & Reference \\
\hline $511 / 10$ & $\begin{array}{l}\mathrm{Py}-\mathrm{Ol} \\
\text { basalt }\end{array}$ & L. Burichi & 2.65 & & 40 & $2.5 \pm 0.5$ & $\begin{array}{l}\text { M. M. Arakelyants } \\
\text { (IGEM), } 1970\end{array}$ \\
\hline $625 / 1$ & $\begin{array}{c}\mathrm{Ol} \\
\text { basalt }\end{array}$ & L. Kuas & 1.67 & & 60 & $5.0 \pm 1.0$ & same, 1970 \\
\hline 624 & $\begin{array}{c}\mathrm{Ol} \\
\text { basalt }\end{array}$ & L. Kuas & 2.04 & & 60 & $1.8 \pm 0.15$ & same, 2000 \\
\hline $625 / 1$ & $\begin{array}{c}\mathrm{Ol} \\
\text { basalt }\end{array}$ & same place & 1.62 & 50 & 40 & $6.0 \pm 1.5$ & [Drubetskoi and Grachev, 1987 \\
\hline $625 / 3 \mathrm{~m}$ & $\begin{array}{c}\mathrm{Ol} \\
\text { basalt }\end{array}$ & same place & 1.80 & 13 & 4 & $3.0 \pm 1.5$ & same \\
\hline $625 / 4$ & $\begin{array}{c}\mathrm{Ol} \\
\text { basalt }\end{array}$ & same place & 1.19 & 160 & 13 & $5.5 \pm 1.0$ & same \\
\hline
\end{tabular}

\section{Geological Setting and Characteristics of the Facies of the Volcanic Rocks}

The deeply eroded river valleys expose the significantly dissected pre-basalt topography of the Udokan Range, with elevations varying for as much as 400-600 m. Products of the volcanic activity have smoothed the topography by filling all lows with lava flows, so that the modern surface topography is amazingly flat and is thus contrastingly different from that before the basalt was erupted.

The topography of the lava fields in the Udokan Range is distinguished for a stepwise morphology, with three major levels at elevations of 1500,1800 , and $2100 \mathrm{~m}$. These levels are eroded in the primary surface of the plateau basalts, whose relics are found in the crest portion of the Udokan Range at elevations of approximately $2400 \mathrm{~m}$. Along with these major cycle surfaces (which are pediments), local steps ranging from $5-10$ to $100-150 \mathrm{~m}$ in width are widespread, and their number depends on the relative height of the slope. A feature usually shared by these surfaces is that they taper off down the strikes of the lava flows.

Facies of the lava flows. All of the examined lava sheets were erupted in subaerial environments. Horizontal flows are most widely spread in, and are typical of, the middle and upper portions of the plateau-basalt piles in the Udokan Range. Deviations from a horizontal position in the bottom portions are explained by the pre-basalt topography and are controlled by the older primary strikes and dips of the rocks. The overlying basalt flows gradually become horizontal.

If the dips of some of the basalt flows were controlled by tectonics, the whole lava pile (from it bottom to top) shows the same strikes and dips, as for example, the 190-m-thick lava pile in the area of Lake Burichi, with all 13 flows dipping $230^{\circ}-240^{\circ} \mathrm{SW}<15^{\circ}-20^{\circ}$.

The thicknesses of the basalt flows vary from 1.5-2 to 30-40 m, with older flows being thicker than the younger ones. It is hard to estimate the true length of the flows. Comparison of selected nearby vertical sections in the crest part of the Udokan Range does not allow their correlation even if the distance between the flows is as small as 500$600 \mathrm{~m}$. Away from the crest, individual flows are sometimes traced for a few kilometers, as for example, in the area of the left-hand tributaries of the Eimnakh River.

The basalt flows are clearly zoned, which is discernible, thanks to well developed and thick cinder zones of red brown color, even from great distances from the outcrops and enables one to easily count the number of individual flows in a given exposed vertical section.

Most of the flows can be subdivided into clearly discernible lower, transitional, and upper (cinder) zones, which differ from one another in the fabric and color of the lava. The lower zone usually consists of massive basalt of black or dark gray color. Depending on its thickness, the porosity of the rocks can be different. If a zone is $1-3 \mathrm{~m}$ thick, pores are constrained to its top portion, whereas thicker zones can be subdivided into lower and upper subzones with a unit of alternating porous and massive basalt in between.

The transitional zones show gradual color variations (lilac shades appear) and an increase in the content (up to 50\%) and size of the pores. The pores are usually open, ellipsoidal, and elongate along the flow direction. The transition to the cinder zone is sharp, and the boundary is uneven.

The cinder zone is typically of red-brown color and consists of cinder, cinder-lava, and lava-breccia, whose thicknesses vary from 1-2 to 5-7 $\mathrm{m}$ depending on their distance from the eruption center. This zone quite often hosts volcanic bombs and granite xenoliths. The rock composing the zone sometimes shows spherical parting, with the cores of the spheres consisting of lava-breccia and with porosity increasing toward the peripheries of the spheres and with the basaltic lava-breccia grading into cinder.

The lava flows are extensively fractured, and the fractures are classified into two types: vertical, in the form of columnar and block parting, and horizontal, as platy parting. The columnar parting is different in the flows of different thickness. In thin (no thicker than 5-6 m) flows, the columns extend all the way from the bottom to top of the flows, whereas the thick flows consist of lower (columns) and upper (entablature) parts. Arrays of horizontal fractures define 
Table 2. Modal Composition (\%) of Volcanic Rocks in the Udokan Range

\begin{tabular}{|c|c|c|c|c|c|c|c|c|c|}
\hline \multirow[t]{2}{*}{ Sample } & \multicolumn{3}{|c|}{ Phenocrysts } & \multirow{2}{*}{$\begin{array}{c}\text { Groundmass (Pl, Ol, } \\
\text { and Cpy microlites) } \\
\text { and volcanic glass }\end{array}$} & \multirow{2}{*}{$\begin{array}{l}\text { Fe-Ti oxides } \\
\text { (magnetite, } \\
\text { ilmenite) }\end{array}$} & \multirow[t]{2}{*}{ Porosity } & \multicolumn{2}{|c|}{ Secondary minerals } & \multirow[t]{2}{*}{ Facies } \\
\hline & $\mathrm{Pl}$ & $\mathrm{Ol}$ & Cpy & & & & Chl & Id & \\
\hline $506 / 6$ & - & 13.7 & - & 81.4 & - & 4.9 & - & - & Lava \\
\hline $511 / 3$ & 25.0 & 38.5 & & 15.8 & 20.7 & - & - & - & Lava \\
\hline $511 / 7$ & - & 16.2 & - & 64.8 & 19.0 & - & - & - & Lava \\
\hline $511 / 10$ & 21.2 & 10.3 & - & 68.5 & - & - & - & - & Lava \\
\hline $511 / 13$ & 19.2 & - & 22.2 & - & 51.6 & - & - & 7.0 & Lava \\
\hline $624 / 10$ & - & 13.8 & 15.0 & 55.2 & 3.1 & 13.7 & - & - & Lava \\
\hline $624 / 13$ & 23.7 & 42.5 & 29.7 & - & 4.1 & - & - & - & Lava \\
\hline $628 / 9$ & 11.3 & 19.8 & 33.1 & - & 9.7 & - & 26.1 & - & Lava \\
\hline $635 / 1$ & 38.1 & 14.4 & 19.3 & - & 17.0 & - & 11.2 & - & Lava \\
\hline $636 / 3$ & 8.7 & - & 7.1 & 52.6 & 16.1 & - & - & - & Lava \\
\hline $510 / 3$ & 34.4 & 40.0 & 17.9 & - & 7.7 & - & - & - & Vent \\
\hline $625 / 4$ & 8.8 & 35.2 & 39.0 & - & 17.0 & - & - & - & Vent \\
\hline $631 / 1$ & 6.0 & 8.2 & 3.3 & 79.6 & 2.9 & - & - & - & Vent \\
\hline $510 / 5$ & 39.5 & 27.8 & 22.9 & - & 9.8 & - & - & - & Explosion \\
\hline
\end{tabular}

systems of platelets whose thicknesses do not exceed $10 \mathrm{~cm}$ (5-6 cm on average). The boundaries between the platelets are poorly pronounced and cannot be traced for a long distance.

The explosion facies is relatively rare and comprises lavas, agglutinates, tuff, tuff-breccia, tuff-sand, and tuffconglomerate, which are often found in the bottom portions of plateau basalt piles, and analogous rocks produced by the Holocene volcanoes (Aku, Syni, and Chepe) [Solonenko, 1966. The rocks were also found on the surface of the plateau basalt and are concentrated near volcanic apparatuses. The clastic material of the tuff-breccia sometimes hosts volcanic bombs and lapilli up to $15-20 \mathrm{~cm}$ across.

The vent facies is widespread and is found mostly as dikes and much more rare necks. The dikes occur mostly in the crest part of the Udokan Range, where they are grouped in arrays of parallel dikes trending NE $40-60^{\circ}$. The average thickness of the dikes is $2-3 \mathrm{~m}$. Locally (in the upper reaches of the Verkhnyaya Chukchudu River) dike-in-dike systems are found. The dikes very often contain xenoliths of various rocks, up to ultramafic nodules [Grachev et al., 1973].

Estimations of the mineral proportions of the volcanic rocks (carried out using a KONTRAST equipment) demonstrate that the rocks of different facies (Table 2 have much in common, and hence, their systematics should be underlain by the chemical composition of the rocks, and their geochemical specifics calls for studying trace elements and REE in these rocks.

\section{Compositional Specifics of the Volcanic Rocks}

Although several aspects of the chemical composition of the rocks composing the lava plateau of the Udokan Range have been described elsewhere [Grachev, 1977] Kiselev et al., 1979 Polyakov and Bagdasaryan, 1986, Rasskazov et al., 1985. Solonenko, 1966 Stupak, 1987, the nature of volcanism in the Udokan Range is so far poorly understood, considering the contrasting differences between volcanism in the southwestern flank of the Baikal Rift and in the Vitim Plateau [Grachev, 1977] Kiselev et al., 1979] Solonenko, 1966 .

In attempt to solve this problem, we sampled the lavas of each flow in two reference vertical sections in the area of Lake Kuas, from which lava samples had been previously analyzed (sampled along the Verkhnyaya Ingamakit, Chukchudu, and Kanksa rivers).

The major-component and normative compositions of the rocks are reported in Table 3 The volcanic rocks from the Udokan Range contain 52.05-58.93\% $\mathrm{SiO}_{2}$, their $\mathrm{Na}_{2} \mathrm{O}$ concentrations are usually higher than the $\mathrm{K}_{2} \mathrm{O}$ concentrations, and $\mathrm{Mg} \#=7.47-78.58$ and characterizes an obvious differentiation trend.

According to the contents of normative olivine, nepheline, and quartz, the rocks are classified into basalt, basanite, tephrite, benmoreite, and trachyte. As seen in the $\mathrm{SiO}_{2}-$ $\left(\mathrm{Na}_{2} \mathrm{O}+\mathrm{K}_{2} \mathrm{O}\right)$ diagram Figure 2), the composition points of the lavas plot as a compact group, and the boundaries between the first three types are gradual. The AFM diagram Figure 3 shows a bimodal distribution of $\mathrm{SiO}_{2}$ and alkalis in the rocks, with a clearly defined Daly gap (the absence of andesite).

Factor analysis (major-component method) reveals a complete and clearly pronounced Bowen differentiation trend (factor I corresponds to a load of $54.9 \%$ and involves $\mathrm{SiO}_{2}$ $\mathrm{K}_{2} \mathrm{O} \mathrm{Al}_{2} \mathrm{O}_{3} \mathrm{Na}_{2} \mathrm{O} / \mathrm{MgO}, \mathrm{CaO}$, and $\mathrm{TiO}_{2}$ ), and factor II $\left(\mathrm{P}_{2} \mathrm{O}_{5}, 15.2 \%\right.$ load $)$ reflects the role of phosphorus, whose concentration systematically varies from 0.07 to $0.73 \%$. The enrichment of the latter component in the melt during its late differentiation can result in the onset of immiscibility between acid and mafic derivatives [Mysen et al., 1981 Ryerson and Hess, 1980. Solonenko, 1966. 


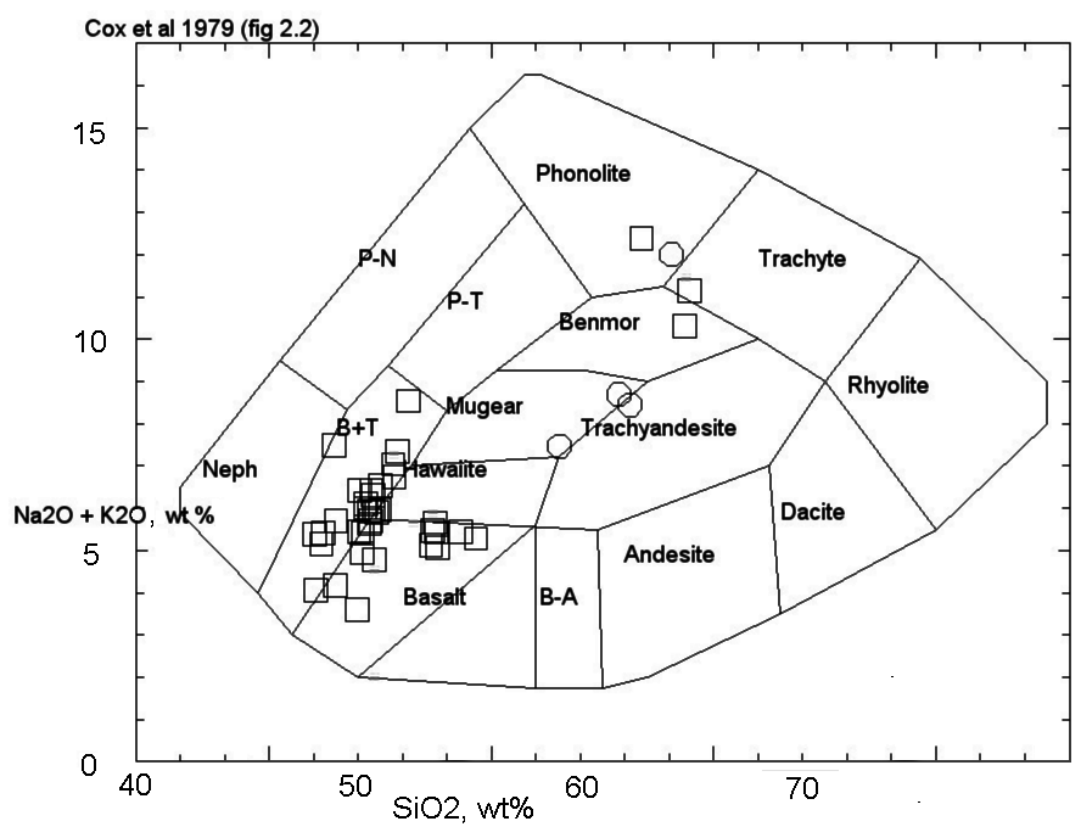

Figure 2. $\mathrm{SiO}_{2}-\left(\mathrm{Na}_{2} \mathrm{O}+\mathrm{K}_{2} \mathrm{O}\right)$ (wt \%) diagram for volcanic rocks in the Udokan Range (boundary lines between rock fields are according to [Cox et al., 1979]).

The petrochemical specifics of volcanics in the Udokan Range is broad variations in their $\mathrm{TiO}_{2}$ content, which varies from 0.22 to $4.41 \%$ Table 2 . Sampling the rocks flow by flow in a 100-m vertical section in the area of Lake Kuas (no hiatuses were detected) led us to discover (Figure 4) that high-Ti basalt $\left(>4.0 \% \mathrm{TiO}_{2}\right)$ composes the bottom por- tion of the section and gives way upward to progressively $\mathrm{Ti}$ poorer rocks (with $\mathrm{TiO}_{2}$ concentration decreasing to $2.5 \%$ ). The decrease in the $\mathrm{TiO}_{2}$ concentrations is negatively correlated with an increase in $\mathrm{P}_{2} \mathrm{O}_{5}$ : the Ti-poor basalt contains no more than $0.1 \% \mathrm{P}_{2} \mathrm{O}_{2}$ while $\mathrm{Ti}$ poorer varieties contain up to $>0.6 \% \mathrm{P}_{2} \mathrm{O}_{5}$ (Table 2 .

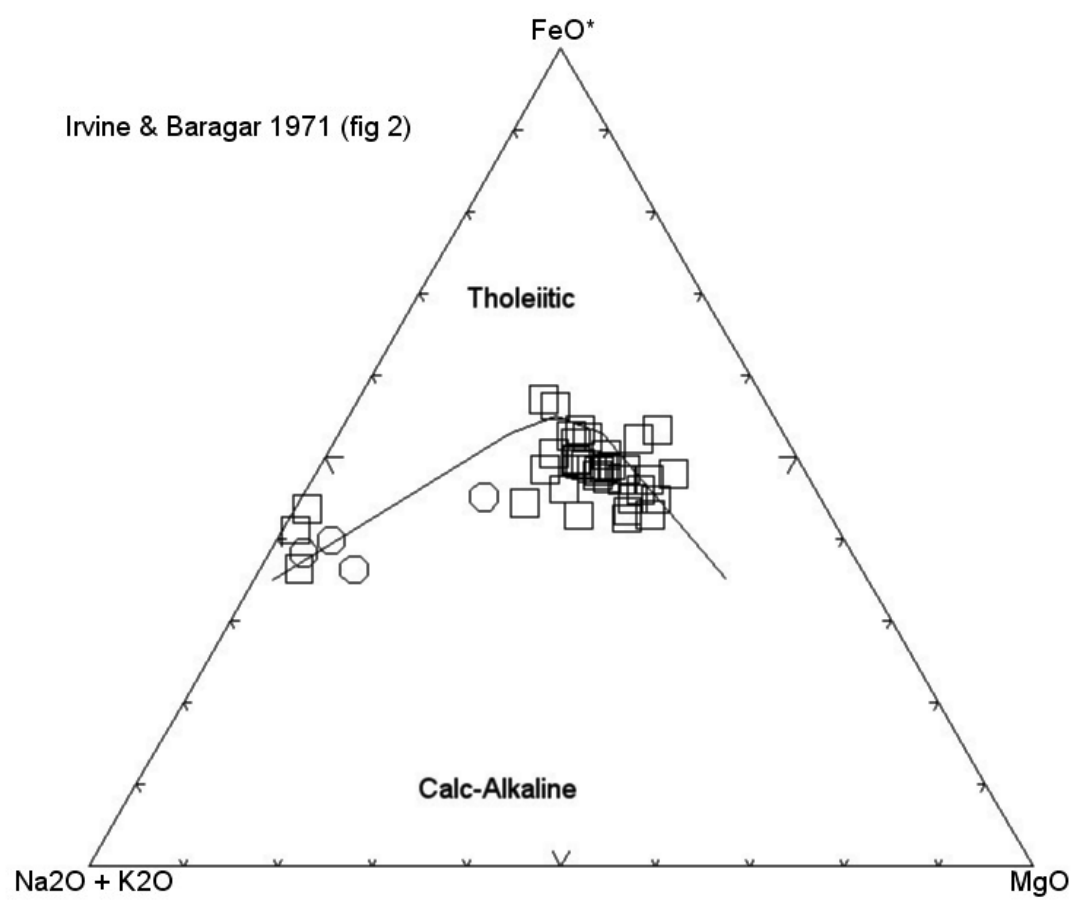

Figure 3. AFM diagram for volcanic rocks in the Udokan Range. See Figure 2 for symbol explanations. 
잉

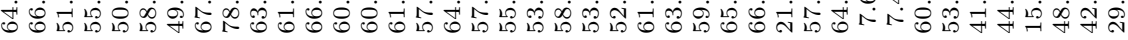

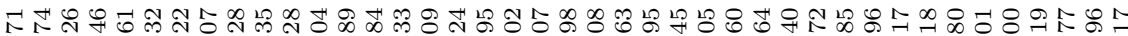
ช̃

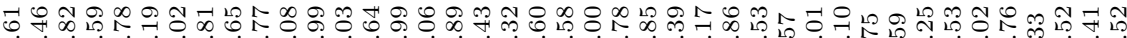

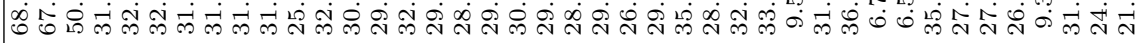

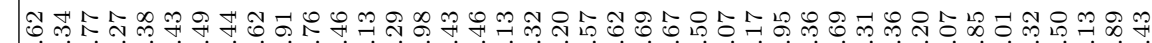

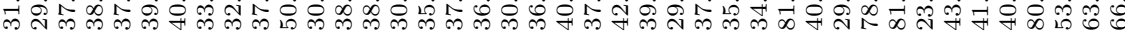

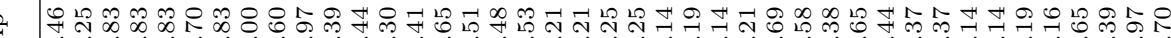

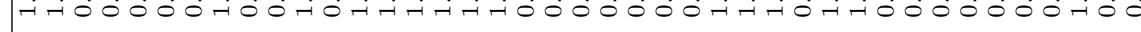

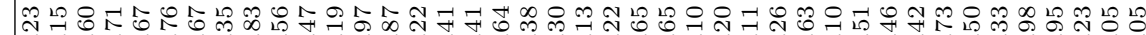

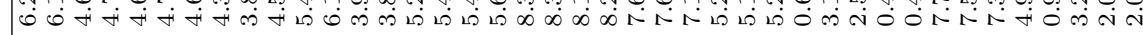

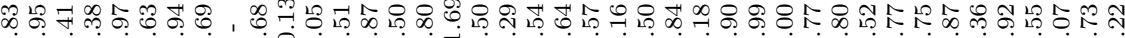

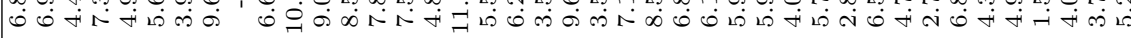
,

只草

우 꿀

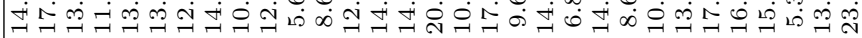

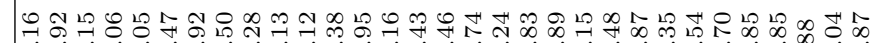

离

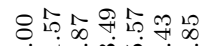

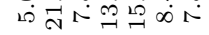

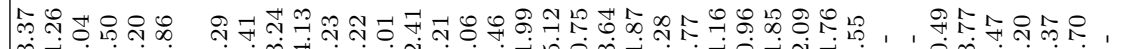

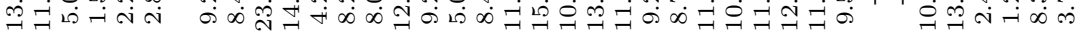

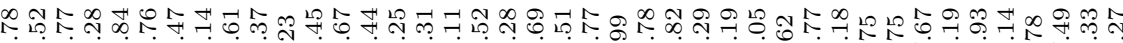

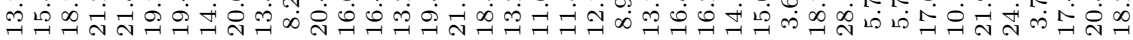

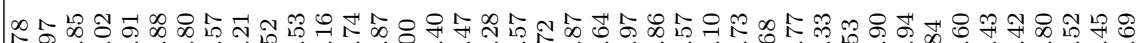

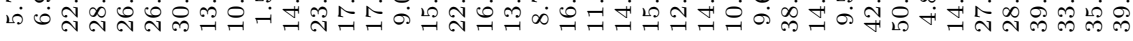

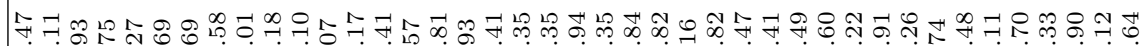

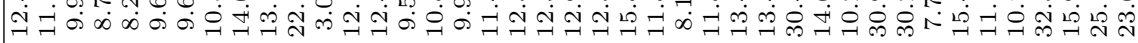

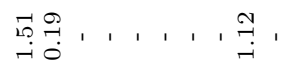

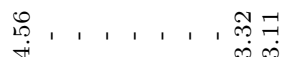

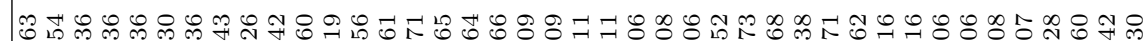

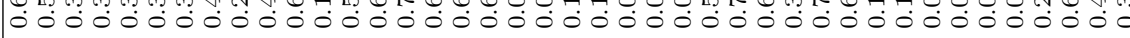

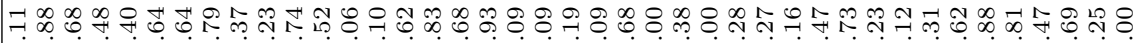

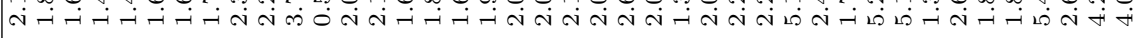
๑

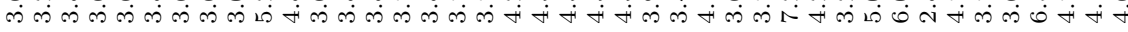

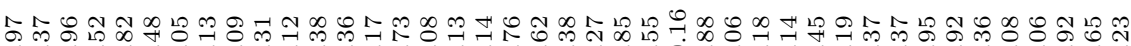

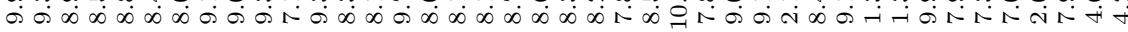

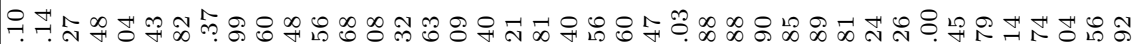
$\exists$ Z

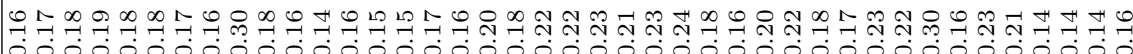

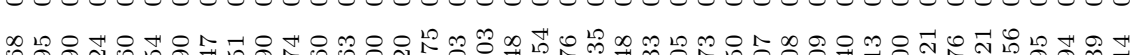

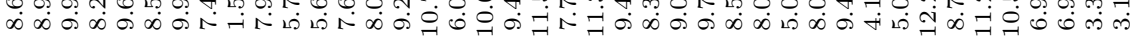

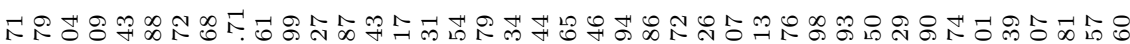

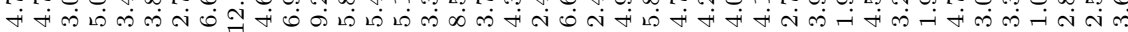

คำㄱำ

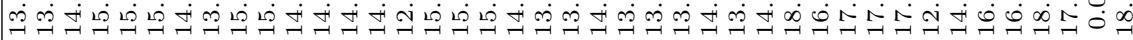

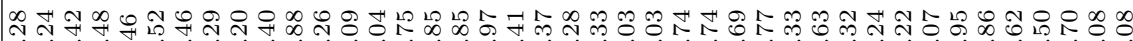
๓

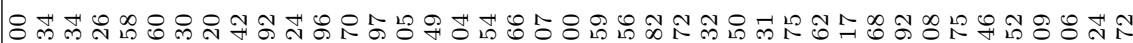

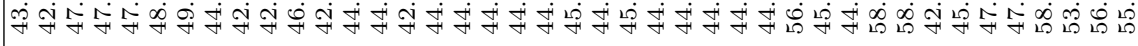

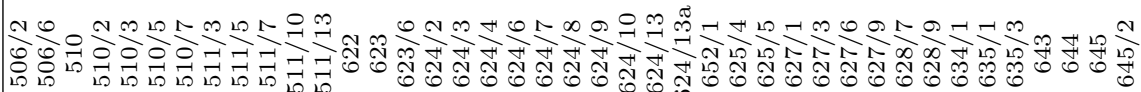




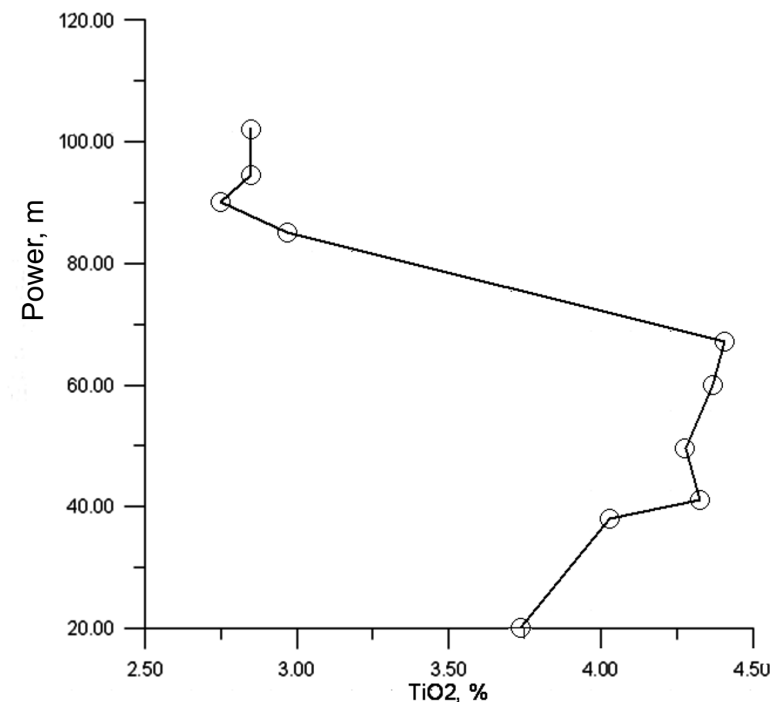

Figure 4. Systematic variations in the $\mathrm{TiO}_{2}$ concentrations of volcanic rocks in the sequence outcropping in the vicinity of Lake Kuas.

Another important trait of the rocks detected when they were studied flow by flow in the Late Pliocene-Quaternary sequence of volcanic rocks is that alkaline basalt alternates with trachyte, as was first noted in [Kiselev et al., 1979 .
Stupak, 1987. The bottom of the vertical section in the vicinity of Lake Kuas is made up of trachyte with clearly seen plate parting. These rocks are overlain by a number of olivine basalt flows (total thickness $100 \mathrm{~m}$ ), which are overlain, again, by a $16-\mathrm{m}$ trachyte unit. It is important to mention that the absent of andesite is seen not only in summarizing diagrams, as on oceanic islands [Baker, 1968 Baker et al., 1964, but also in individual vertical sections of volcanic rocks in the Udokan Range.

Table 4 reports the concentrations of trace elements and REE. According to their $\mathrm{Cr}, \mathrm{Ni}$, and Co concentrations, the Udokan volcanics are classified into two groups: one of them comprises rocks rich in $\mathrm{Cr}(>100 \mathrm{ppm}), \mathrm{Ni}(>80 \mathrm{ppm})$, and Co $(>50 \mathrm{ppm})$, and the other is defined by rocks poorer in these elements. Note that these groups also differ in $\mathrm{TiO}_{2}$ concentration: the high-Cr volcanics contain up to $4.4 \%$ $\mathrm{TiO}_{2}$ while the low-Cr ones bear no more than $2.8 \%$. Factor analysis of major and trace elements shows that $\mathrm{Cr}, \mathrm{Ni}, \mathrm{Co}$, and $\mathrm{P}_{2} \mathrm{O}_{5}$ are negatively correlated with $\mathrm{TiO}_{2}$, i.e., the composition of melt in the sequence of volcanic rocks in the Lake Kuas area evolved with enrichment in $\mathrm{P}_{2} \mathrm{O}_{5}$ and depletion in $\mathrm{Cr}, \mathrm{Ni}, \mathrm{Co}$, and $\mathrm{TiO}_{2}$.

These data led us to suggest that the volcanic activity evolved cyclically and resulted in alternating volcanic rocks of different major-component and trace-element composition. The high $\mathrm{TiO}_{2}$ concentration in the basalt likely reflects the content of Ti-bearing minerals in the mantle source [Xirouchakis et al., 2001]. The high Cr concentration may be explained analogously.

Table 4. Representative Analyses of Trace Elements and REE (ppm) in Late Pliocene-Quaternary Volcanic Rocks in the Udokan Range

\begin{tabular}{|c|c|c|c|c|c|c|c|c|c|c|c|}
\hline & $510 / 5$ & $511 / 3$ & $511 / 13$ & 532 & 623 & $624 / 2$ & $624 / 3$ & $624 / 13 \mathrm{a}$ & $625 / 1$ & 644 & $645 / 2$ \\
\hline $\mathrm{Sc}$ & 20.2 & 26.6 & 21.5 & 19.7 & 18.6 & 14.5 & 15.1 & 24.6 & 18 & 10.7 & 5.9 \\
\hline $\mathrm{Cr}$ & 217 & 117 & 160 & 193 & 334 & 243 & 194 & 308 & 259 & 102 & 9.5 \\
\hline $\mathrm{Co}$ & 45.4 & 47.7 & 45.1 & 44.9 & 51.2 & 56.5 & 60 & 63.9 & 60 & 25.7 & 10.4 \\
\hline Cs & $<0.5$ & $<0.5$ & $<0.5$ & 0.20 & 0.20 & $<0.5$ & 0.8 & $<0.5$ & $<0.5$ & 1.2 & $<0.5$ \\
\hline Hf & 4.36 & 4.79 & 3.54 & 5.59 & 4.37 & 6.5 & 4.9 & 4.03 & 5.5 & 6.9 & 5.7 \\
\hline $\mathrm{Ta}$ & 2.06 & 2.42 & 0.95 & 3.34 & 4.81 & 4.49 & 2.85 & 3.78 & 3.10 & 4.14 & 3.27 \\
\hline Th & 2.9 & 3.21 & 1.6 & 4.5 & 4.30 & 4.4 & 4.2 & 3.42 & 4.1 & 7.6 & 6.3 \\
\hline $\mathrm{U}$ & 1.4 & $<1.0$ & $<1.0$ & 1.8 & 1.40 & 1.5 & 2.1 & 0.91 & 1.5 & 2.8 & 2.3 \\
\hline $\mathrm{Rb}$ & - & 30 & $<20$ & 39 & 37 & - & - & $<20$ & - & - & - \\
\hline $\mathrm{Sr}$ & - & 273 & 384 & 938 & 760 & - & - & 549 & - & - & - \\
\hline $\mathrm{Y}$ & - & 31 & $<15$ & 22 & 620 & - & - & $<15$ & - & - & - \\
\hline $\mathrm{Zr}$ & - & 210 & 149 & 355 & 340 & - & - & 204 & - & - & - \\
\hline $\mathrm{Nb}$ & - & - & 23 & - & - & - & - & - & - & - & - \\
\hline $\mathrm{Ba}$ & - & 610 & 356 & 700 & 820 & - & - & 447 & - & - & - \\
\hline $\mathrm{La}$ & 28.40 & 26.73 & 15.30 & 40.00 & 45.20 & 33.60 & 40.90 & 27.01 & 38.70 & 52.40 & 40.90 \\
\hline $\mathrm{Ce}$ & 53.60 & 58.70 & 32.10 & 78.60 & 79.90 & 61.90 & 79.70 & 52.80 & 64.40 & 89.60 & 70.40 \\
\hline $\mathrm{Nd}$ & 22.00 & 65.00 & 28.00 & 18.00 & 25.00 & 57.00 & 71.00 & 61.00 & 33.00 & 48.00 & 35.00 \\
\hline $\mathrm{Sm}$ & 5.88 & 7.81 & 4.52 & 7.51 & 7.37 & 7.01 & 8.14 & 5.92 & 7.91 & 8.03 & 5.77 \\
\hline $\mathrm{Eu}$ & 1.76 & 2.47 & 2.54 & 2.16 & 2.34 & 2.25 & 2.47 & 1.96 & 2.36 & 2.36 & 2.09 \\
\hline $\mathrm{Tb}$ & 0.79 & 1.24 & 0.92 & 0.46 & 1.08 & 1.08 & 1.04 & 0.78 & 1.13 & 1.13 & 0.91 \\
\hline $\mathrm{Yb}$ & 1.71 & 3.13 & 1.33 & 1.32 & 1.48 & 1.18 & 1.44 & 1.90 & 1.18 & 2.52 & 2.48 \\
\hline $\mathrm{Lu}$ & 0.24 & 0.94 & 0.11 & 0.42 & 0.15 & 0.13 & 0.14 & 0.43 & 0.20 & 0.32 & 0.29 \\
\hline
\end{tabular}

Note: Sampling sites: samples 510-511 (L. Burichi), 532 (southwestern termination of the China-Vakatskii Fault), 623 (upper reaches of the Chukchudu R.), 624 and 625 (upper reaches of the Kuas R.), 644, 645/2 (area of Chepe volcano). 
Norm: SUN

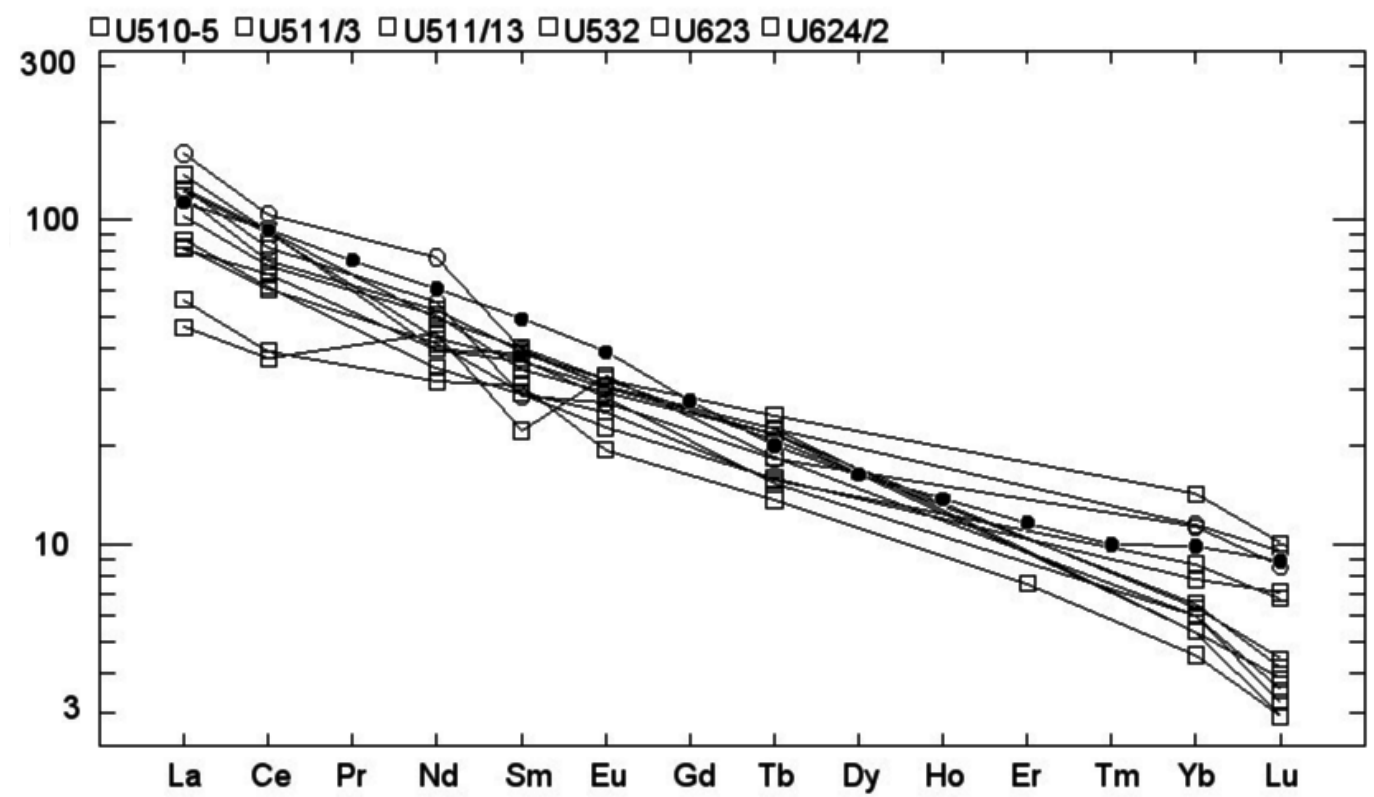

Figure 5. Chondrite-normalized REE patterns for volcanic rocks in the Udokan Range. See Figure 2 for symbol explanations. Solid circles are OIB [McDonough and Sun, 1995].

The REE patterns shows that the Udokan volcanics evolved along a trend analogous to that of OIB (Figure 5), with enrichment in LREE and depletion in HREE. In contrast to OIB, both basalts from the Udokan Range and mantle nodules in these rocks typically posses very low ${ }^{3} \mathrm{He} /{ }^{4} \mathrm{He}$ ratios Drubetskoi and Grachev, 1987.

\section{Discussion and Conclusions}

Volcanic rocks in the Udokan Range differ from products of Cenozoic volcanic activity elsewhere within the Baikal Rift Zone in possessing unusual facies and chemical compositions.

The volcanic rocks display the following distinguishing compositional features: (1) the lavas show a bimodal distribution of their chemical compositions, with a Bowen differentiation trend and a Daly gap; this is typical of both the plateau basalts and the rocks of the central volcanoes; (2) the rocks are rich in $\mathrm{TiO}_{2}(>4 \%)$; and (3) the compositional evolution of the volcanics involves enrichment in $\mathrm{P}_{2} \mathrm{O}_{5}$ and depletion in $\mathrm{Cr}, \mathrm{Co}$, and $\mathrm{Ni}$. These features of volcanism in the Udokan Range are closely similar to those of volcanic processes at such oceanic islands as, for example, the Tristan da Cunha Islands [Baker et al., 1964].

Data of chemical geodynamics show that volcanism in the southwestern part of the Baikal Rift (in the Khamar Daban Range and Tunka depression) and in the Vitim Plateau developed under the effect of mantle plumes [Grachev, 1998 . Johnson et al., 2005, whose presence was inferred from geophysical data [Zorin et al., 2003]. It was also hypothesized [Zorin et al.,2003] that a mantle plume occurs in the area of the Udokan Range. This puts forth the question as to which geochemical features (if any) of the Udokan lavas may reflect the influence of this plume.

In this context, it is worth mentioning first of all the high $\mathrm{TiO}_{2}$ concentrations of the lavas, which reach $>4$ wt $\%$ in the basanite and basalt (Table 2). No such high $\mathrm{TiO}_{2}$ concentrations are found in either any other volcanic rocks in the southwestern flank of the Baikal Rift [Grachev, 1998 or volcanics in the Vitim Plateau [Johnson et al., 2005]. It is also important that the high-Ti basalts, containing $>4.0$ wt $\% \mathrm{TiO}_{2}$, compose the bottom parts of the volcanic piles and give way to $\mathrm{Ti}$ poorer lavas (containing no more than $2.5 \mathrm{wt} \% \mathrm{TiO}_{2}$ ) upsection. The systematic variations in the $\mathrm{TiO}_{2}$ concentrations are correlated with those of $\mathrm{P}_{2} \mathrm{O}_{5}$ : the high-Ti basalt contains no more than $0.1 \%$ $\mathrm{P}_{2} \mathrm{O}_{5}$ whereas basalts poorer in Ti are richer in $\mathrm{P}_{2} \mathrm{O}_{5}$ (contain as much as $0.6 \%$ ) Table 2). It is also worth mentioning the high $\mathrm{MgO}$ concentrations (up to 11\%) of basanite and basalt from the Udokan Range.

Associations of lavas rich and poor in $\mathrm{TiO}_{2}$ are typical of areas with flood basalts worldwide [Gibson et al., 1995 Mahoney and Coffin, 1997, and several others]. However, unlike flood basalts, whose high- and low-Ti basalts differ in $\mathrm{Sm}$ and $\mathrm{Nd}$ isotopic ratios [Gibson et al., 1995] Xiao et al., 2004, these ratios in the lavas in the Udokan Range are similar, regardless of the $\mathrm{TiO}_{2}$ concentrations of these rocks [Harris, 1998].

With regard for the fact that the lavas with high and low $\mathrm{Ti}$ concentrations occur together and are coeval, that their geochemistries are similar, and all of the lavas contain spinel lherzolite nodules, it is reasonable to suggest that the bimodal basalt-trachyte series was derived from a single 
mantle source related to a mantle plume. The high $\mathrm{TiO}_{2}$ concentration of the Udokan basalts may reflect the content of Ti-bearing minerals in the mantle source [Xirouchakis et al., 2001.

\section{References}

Amirkhanov, Kh. I., A. S. Batyrmurzaev, I. O. Gargantsev, M. R. Omarova, S. Z. Gadzhiev (1985), Age of volcanic basalts in the Udokan depression, Baikal Rift Zone, and the area of Lake Khubsugul, Mongolia, Dokl. AN SSSR, 285, No. 2, 411-413.

Bagdasaryan, G. N., et al. (1981), Newly obtained data on the isotopic age and chemical composition of volcanic rocks in the Baikal Rift Zone, Geokhimiya, No. 3, 342-350.

Baker, I. (1968), Intermediate oceanic volcanic rocks and the "Daly gap", Earth Planet. Sci. Lett., 4, 103-106, doi:10.1016/0012-821X(68)90002-2

Baker, P. E., I. G. Gass, P. G. Harris, R. W. Le Maitre (1964), The volcanological report of the Royal Society expedition to Tristan Da Cunha, 1962, Phil. Trans. Roy. Soc. London. Series A, 256, No. 1075, 439-578.

Cox, K. G., J. D. Bell, R. J. Pankhurst (1979), The Interpretation of Igneous Rocks, Chapman \& Hall, London. doi:10.1007/978-94-017-3373-1

Gibson, S. A., R. N. Thompson, A. P. Dickin, O. H. Leonardos (1995), High-Ti and Low-Ti mafic potassic magmas: Key to plume-lithosphere interactions and continental floodbasalts genesis, Earth Planet. Sci. Lett., 136, 149-165, doi:10.1016/0012-821X(95)00179-G

Grachev, A. F. (1977), Rift Zones of the Earth, Nedra, Leningrad.

Grachev, A. F. (1998), Khamar Daban, a hotspot in the Baikal Rift: chemical geodynamic evidence, Fizika Zemli, No. $2, \quad 3-28$.

Grachev, A. F., E. I. Blyumshtein, E. P. Sokolova, A. I. Levykin (1973), Lherzolite nodules in alkaline basalt from the Baikal Rift, Dokl. AN SSSR, 211, No. 2, 445-447.

Drubetskoi, E. R., A. F. Grachev (1987), Helium and argon isotopes in basanites and ultramafic nodules in the Baikal Rift Zone, Mantle Xenoliths and the Structure of the Lithosphere p. 54-69, Nauka, Moscow.

Harris, N. R. (1998), Isotopical, Geochemical and Geochronological Constraints on the Origin and Evolution of Cenozoic Volcanism, Baikal Rift Zone, Siberia, 438 pp., MIT, Boston.

Johnson, J. S., S. A. Gibson, R. N. Thompson, G. M. Nowell (2005), Volcanism in the Vitim volcanic field: geochemical evidence for a mantle plume beneath the Baikal rift zone, Jour. Petrology, 46, 1309-1344, doi:10.1093/petrology/egi016

Kiselev, A. I., M. E. Medvedev, G. A. Golovko (1979), Volcanism in the Baikal Rift Zone and Problems of Deep-Sitting Magma Generation, 197 pp., Nauka, Novosibirsk.

Mahoney, J. J., M. F. Coffin, (eds.) (1997), Large Igneous Provinces, Am. Geophys. Union Monograph 100 p. 438, AGU, W.

McDonough, W. F., S.-s. Sun (1995), The composition of the Earth, Chem. Geol., 120, 223-253, doi:10.1016/00092541(94)00140-4

Muzis, A. 1. (1970), Cenozoic rocks and modern tectonics in the Olekma-Vitim Highland, Cand. Diss. (geol.-mineral.), p. 24, IFZ RAS, Moscow.

Mysen, B. O., F. J. Ryerson, D. Virgo (1981), The structural role of phosphorus in silicate melts, Am. Min., 66, 106-117.

Polyakov, A. I., G. P. Bagdasaryan (1986), On the age of young volcanic rocks in eastern Siberia and evolutionary tendencies of their composition, Geokhimiya, No. 3, 311-317.

Rasskazov, S. V. (1985), Basaltoids of Udokan, $142 \mathrm{pp}$., Nauka, Novosibirsk.

Rasskazov, S. V., et al. (2000), Geology and Geodynamics in the Late Cenozoic: Southern Siberia and Southeast Asia, 288 pp., Nauka, Novosibirsk.

Ryerson, F. J., $\quad$ P. C. Hess (1980), The role of $\mathrm{P}_{2} \mathrm{O}_{5}$ in silicate melts, Geochim. Cosmochim. Acta, 44, 611-625, doi:10.1016/0016-7037(80)90253-7

Solonenko, V. P., (ed.) (1966), Live Tectonics, Volcanoes, and Seismicity of the Stanovoi Highland, 230 pp., Nauka, Moscow.

Stupak, F. M. (1987), Cenozoic Volcanism in the Udokan Range, 169 pp., Nauka, Novosibirsk.

Xiao, L., Y. G. Xu, H. J. Mei, Y. F. Zheng, B. He, F. Pirajno (2004), Distinct mantle sources of low-Ti and high-Ti basalts from the western Emeishan large igneous province, SW China: implications for plume-lithosphere interactions, Earth Planet. Sci. Lett., 228, 525-546, doi:10.1016/j.epsl.2004.10.002

Xirouchakis, D., M. M. Hirschmann, J. A. Simpson (2001), The effect on the silica content and on mineral-liquid partitioning of mantle-equilibrated melts, Geochim. Cosmochim. Acta, 65, 2201-2217, doi:10.1016/S0016-7037(00)00549-4

Zorin, Yu. A., E. Kh. Turutanov, V. M. Kozhevnikov (2003), Mantle plumes beneath the Baikal rift zone and adjacent areas: geophysical evidence, Doklady Earth Sciences, 393a, 13021304 .

A. F. Grachev, Schmidt Institute of Physics of the Earth, Russian Academy of Sciences, 10 Bolshaya Gruzinskaya, Moscow, Russia. (afgrachev@gmail.com) 